\title{
Oilseed and protein crops grown in French organic farms: an overview of cultivation practices for sunflower and soybean ${ }^{\text {it }}$
}

\author{
Cécile Le Gall ${ }^{1, *}$, Vincent Lecomte ${ }^{2}$ and Dominique Wagner ${ }^{1}$ \\ 1 Terres Inovia, Avenue Lucien Brétignières, 78850 Thiverval Grignon, France \\ 2 Terres Inovia, 6 Chemin de la Côte Vieille, 31450 Baziège, France
}

Received 27 April 2021 - Accepted 9 November 2021

\begin{abstract}
The development of organic agriculture in France was steady since 2010 but became stronger since 2014. Like other crops, the cultivated areas of organic soybean and sunflower doubled from 2014 to 2018. With a view to better characterize cultural practices in organic production, Terres Inovia and ITAB (in collaboration with Agence Bio) conducted in 2016 and 2017 a national farmers' survey. These surveys reveal that sunflower was mainly cultivated over the same types of soil than in conventional production but were integrated in more diversified rotations. The main differences between organic and conventional systems concern sowing date and weed control. Organic sunflower was sown very lately compared to conventional one, which impacted the yield severely. Weed were controlled through ploughing, mechanical weeding and crop rotation and weed control was judged as satisfying by a major part of producers. Concerning soybean, a great difference is the use of irrigation which is almost systematic in conventional but concerned only $50 \%$ of cultivated area in organic production. Contrary to sunflower, soybean is integrated in short crop rotation, particularly when it was irrigated. This demonstrated the high profitability of soybean in organic systems. Like for sunflower, weed control done through ploughing, mechanical weeding, and crop rotation and weed control was also judged satisfying; nevertheless, criteria on harvest impurities are more severe and to respect them, organic farmers also use hand weeding in complement. These surveys will be reconducted over the years to be able to follow the changes of cultural practices over the years.
\end{abstract}

Keywords: organic production / soybean / sunflower / cultural practices / Survey

Résumé - Les cultures oléagineuses et protéagineuses dans l'agriculture biologique française : une synthèse des pratiques culturales pour le tournesol et le soja. Le soja et le tournesol, comme d'autres espèces, ont vu leurs surfaces doubler sur la période 2014-2018. Afin de mieux connaître les pratiques culturales sur ces cultures, Terres Inovia et l'ITAB (en collaboration avec l'Agence Bio) ont réalisé en 2016 et 2017 une enquête nationale auprès des producteurs. Ces enquêtes ont révélé que le tournesol était implanté dans des milieux similaires au conventionnel, mais dans des rotations plus diversifiées. Les points de différence majeures entre conduites biologique et conventionnelle concernaient la date de semis et la gestion des adventices. Le tournesol biologique était semé beaucoup plus tard et ce décalage impactait sévèrement le rendement. La gestion des adventices en conditions biologiques s'était faite au travers du labour, du désherbage mécanique et de la rotation des cultures. Concernant le soja, la différence majeure entre conduite conventionnelle et biologique est le recours à l'irrigation qui était quasi systématique en conventionnel alors qu'elle ne concernait que $50 \%$ des surfaces en conduite biologique. Contrairement au tournesol, le soja était intégré dans des rotations relativement courtes, notamment en conduite irriguée. Cela démontre la forte rentabilité du soja en système biologique. Comme pour le tournesol, la maitrise de l'enherbement était un point crucial : elle était assurée aussi via le labour, le désherbage mécanique et la rotation culturale mais, le cahier des charges sur les impuretés étant plus sévère, les agriculteurs avaient aussi régulièrement recours au désherbage manuel. Ces enquêtes seront reconduites régulièrement afin d'être en mesure de suivre l'évolution des pratiques culturales au cours du temps.

Mots clés : agriculture biologique / soja / tournesol / pratiques culturales / Survey

\footnotetext{
is Contribution to the Topical Issue "Organic foods in the oil \& protein crop supply chain / Le «Bio » dans la filière oléoprotéagineuse".

*Correspondence: c.legall@terresinovia.fr
} 


\section{Introduction}

The development of organic agriculture in France was steady since 2010 but became stronger since 2014 . For arable crops, we observed from 2014 to 2018 a strong increase of cultivated areas for oilseed and protein crops, particularly for sunflower, soybean, pulses (chick-pea and lens) and legumecereal intercrop (see Fig. 1; data from Agence Bio, 2019).

In 2018, cereals (and particularly winter cereals) represented $63 \%$ of the total area cultivated with field crop. Legume-cereal intercrops represented $12 \%$ of the cultivation area whie oilseed crops and soybean represented $10 \%$ of the cultivation area. Protein crops (peas, faba beans and lupin) and pulses (lens and chickpeas) both represented 5\% of this cultivation area (Agence Bio, 2019). Compared to non-organic agriculture, rapeseed cultivated areas were very low (due to strong difficulties with pest control and nitrogen nutrition) whereas soybean and sunflower ones were very important. Indeed, in France, the major part of organic arable crops is cultivated in South West of France where soybean and sunflower were historically present. Pea cultivated areas are lower than faba bean ones, mainly because pea is more difficult to grow under organic farming conditions and because faba bean offers a higher grain protein rate for livestock feeding. However, pea is still important in crop rotations but is mainly intercropped with cereals.

Thus, the development of organic cultivated areas is unequal at regional scale. In 2014, and still in 2018, Occitanie and Nouvelle-Aquitaine remained the two most important regions, with cumulated oilseed and protein crops cultivated areas that exceeded 25000 ha in 2018 (44 949 ha for Occitanie and 26465 ha for Nouvelle-Aquitaine). For BourgogneFranche-Comté, Auvergne-Rhône-Alpes, Centre-Val de Loire, Grand Est and Pays de la Loire, the cumulated cultivated areas varied from 9000 to 13000 ha. The last four regions (Bretagne, Île-de-France, PACA, Normandie, Hauts-de-France) had the lowest cumulated cultivated areas, with less than 7000 ha each. Nevertheless, the balance is modified if we separate oilseed and protein crops. For oilseed, Auvergne-Rhône-Alpes and Bourgogne-Franche-Comté are respectively the 3rd and the 4th most important regions for soybean and sunflower whereas it is respectively Centre-Val de Loire and Pays de la Loire for protein crops (Pays de la Loire is even the 1st region for legume-cereal intercrops).

Beyond Figure 2, it also is important to look at the development dynamic of organic cultivated areas in these different regions. The region Occitanie is the region where the development was the strongest, with a 2.4-fold increase of organic cultivated areas between 2014 and 2018. Nevertheless, some regions with still low organic cultivated areas (Grand Est, Bretagne, Normandie and Hauts-de-France) had showed similar increase (2.5-fold to 2.7-fold) over the same period. Figure 2 shows that we will probably observe, in the next 10 years, a progressive rebalance of organic cultivated areas among the French regions, with a step-up of the northern regions.

Figure 2 shows that oilseed and protein crops production is presently undergoing an important scale up. New territorial dynamics are setting up, which are leading to major changes of cultivation practices for oilseed and protein crops, because they are produced on new areas, with soil and climate conditions that are different from the historical production area.

To be able to follow these changes over the years, Terres Inovia and ITAB (in collaboration with Agence Bio) conduct regularly surveys on soybean and sunflower cultivation practices. Producers are questioned about their motivations to cultivate these crops, the key factors for success (or failure), the average yields and the technical itineraries. These surveys are conducted on each crop separately, and repeated over the years, to follow the changes. The last survey was conducted in 2016 for soybean (previous one: 2012) and in 2017 for sunflower (previous one: 2011). For these 2 crops, a survey was also conducted on farms with conventional production over the same years. Results were analysed with the same method, so the data obtained can be compared.

In addition to the follow-up of the evoluton of agricultural practices over the years, these surveys aim (i) to point out the main difficulties encoutered by producers (and so define research and development programs to solve them), (ii) to better explain the relationship between agricultural practices and crop performances (yield and grain quality essentially) and (iii) provide a base to imagine which could be the innovating technical itinearries of tomorrow.

\subsection{Surveys method}

Each survey was carried out on a single crop. The survey questionnaire was sent to farmers (choice based upon data provided by Agence Bio, the French institution in charge of communication and promotion on organic products and value chains, and to collect data on the development of organic agriculture in France). The survey questioned farmers about: farm type (specialised in arable crop or livestock-crop farming), conversion year, total cultivated area, cultivated area of the crop selected for the survey, crop rotation, tillage, sowing (date, density, row spacing), variety, cover crop, fertilisation, weed control, crop protection, harvest, yield and grain quality.

The survey questionnaire was sent by Terres Inovia just after harvest time (of each selected crop) and the survey was often closed in January or February of the next year. Return rate varied from $5 \%$ to $20 \%$ depending on the crop: indeed, it was far much difficult to obtain voluntary returns for crops with low cultivated areas.

For data-analysis, answers from different regions were analysed separately. However, as the return rate can be too low for some regions, data from adjacent regions were pooled. Most of the time, 3 to 5 groups of regions were defined (see Tabs. 1 and 2). Only groups of regions with more than 20 available data were considered as representative: below, no analysis was conducted. For the survey conducted on sunflower in 2017, only data from southern and westerncenter regions of France were analysed; for the survey conducted on soybean in 2016, only data from southern regions of France could be analysed. Results were expressed through percentage of respondents or percentage of area covered. 


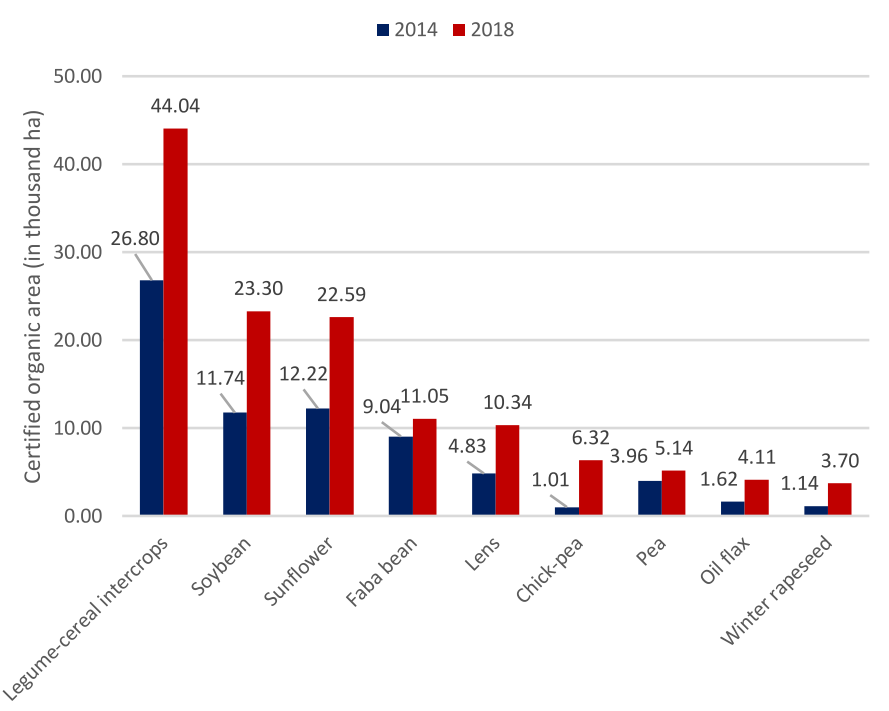

Fig. 1. Evolution from 2014 to 2018 of areas cultivated under organic conditions of oilseed and protein crops (From Agence Bio, 2019).

\section{Sunflower: a trade-off to find between different goals}

\subsection{Organic rotations with sunflower are diversified}

As for non-organic sunflower, organic sunflower is cultivated mainly in farms specialised in arable crops. Nevertheless, farms with livestock represent $30 \%$ of the total survey area for the southern production area and $34 \%$ for the western-center area of production (see Figs. 3 and 4).

On these two areas of production, sunflower is usually cultivated after winter soft wheat and is present on a field less than one year out of four. This delay is a major asset to control some diseases like mildew. Crop rotations with sunflower are more diversified in organic farms compared to non-organic ones. One good indicator is the number of different crops sown in the 5 years preceding sunflower on the same field. As shown in Table 3, this number is higher for organic crop rotations compared to conventional one.

Besides, on $40 \%$ of the total survey area, sunflower is preceded by a cover crop in organic rotations. This situation is more frequent in the western-center area with $46 \%$ of the sunflower cultivated area with a cover crop before sunflower and is similar to the trend observed for non-organic sunflower on the same area. On the contrary, on the southern area, $32 \%$ of the organic sunflower area is covered by a cover crop before sunflower instead of only $6 \%$ of the cultivated area for nonorganic sunflower.

On southern and western-center areas, cover crops are a mixture of several species, including legumes, for organic sunflower whereas it is mostly mustard for non-organic sunflower.

\subsection{Sowing realised in good conditions but very late}

On the western-center area, results indicated that sunflower is generally cultivated on farms that also cultivate a lot of maize. Consequently, sunflower is often sown like maize, with wide row-spacing (52\% of the total survey area). On the contrary, on the southern area where maize cultivation is more limited, only $25 \%$ of the total survey area is sown with wide row spacing. Sowing density varies from 70000 to 75000 seeds/ha, which is higher than for non-organic sunflower (from 65000 to $75000 \mathrm{seeds} / \mathrm{ha}$ ). This trend can be explained by the need under organic conditions to anticipate the losses of plants due particularly to mechanical weeding damages. The same trend is also observed for soybean on the same areas $(450000$ seeds/ha for organic soybean instead of 410000 seeds/ha for non-organic soybean).

Plant losses before emergence (due to birds) or just after (due to birds or other wild game) were more important for the the western-center area: as shown in Figures 5 and 6. Pigeons are responsible for a major part of these damages on the southern area but are frequently associated with damages from hare on the western-center area.

For southern and western-center regions, median sowing date was on May, 10th but the sowings began at the beginning of April and ended at the beginning of June, 1st. For nonorganic sunflower surveyed the same year, the sowing period was more limited, from the beginning to the end of April (based upon the survey conducted by Terres Inovia on agricultural practices for non organic sunflower in 2016). This difference can be explained by two reasons. Firstly, organic producers wait for the non organic best climatic conditions for sowing (particularly soil temperature) to be sure that sunflower grows rapidly and can compete with weeds at first development stages. Secondly, to limit weeds development during sunflower cultivation, they have to harrow the field several times before sunflower sowing (to create a false seed bed for weeds and then destroy them).

Nevertheless, such late sowing dates penalize sunflower yield because the sunflower is much more exposed to water stress at susceptible stages. This was clear in 2017, where the average yield for non-organic sunflower was of $27 \mathrm{q} / \mathrm{ha}$ instead of only $22 \mathrm{q} / \mathrm{ha}$ for organic sunflower on the same regions (with a very low pest and disease pressure). Sowing sunflower earlier would imply to harrow the fields much earlier, as soon as January, but it would not be easy when a cover crop is present. Indeed in 2017, the major part of cover crops was ploughed after mid-April.

\subsection{Good weed control}

The weeds which are the most feared by the producers are goosefoot (Chenopodium sp.), thistle (Circium arvense), barnyard grass (Echinochloa sp.), amaranth (Amarantus sp.), jimsonweed (Datura stramonium), and cocklebur (Xanthium).

Sunflower is usually ploughed as shown in Figures 7 and 8. Ploughing is one of the most effective practice to limit weed development. Besides, as a good soil structure is necessary for the sunflower emergence and growth, it also improve the sunflower ability to compete with weeds.

Mechanical weeding is largely used for sunflower, especially because sunflower is sown with wide row spacing and so can be hoed. Mechanical weeding seemed to be less intensive for producers still in-conversion (1 harrowing or hoeing instead of 3 to 4 for producers who have already 


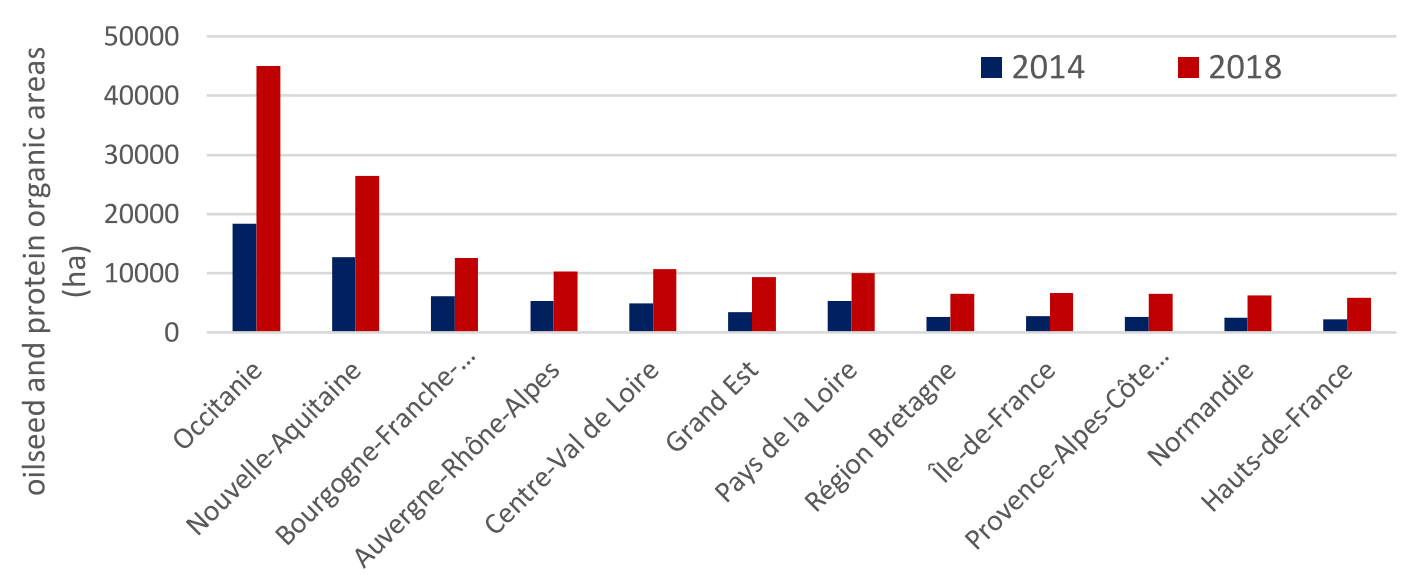

2014

2018
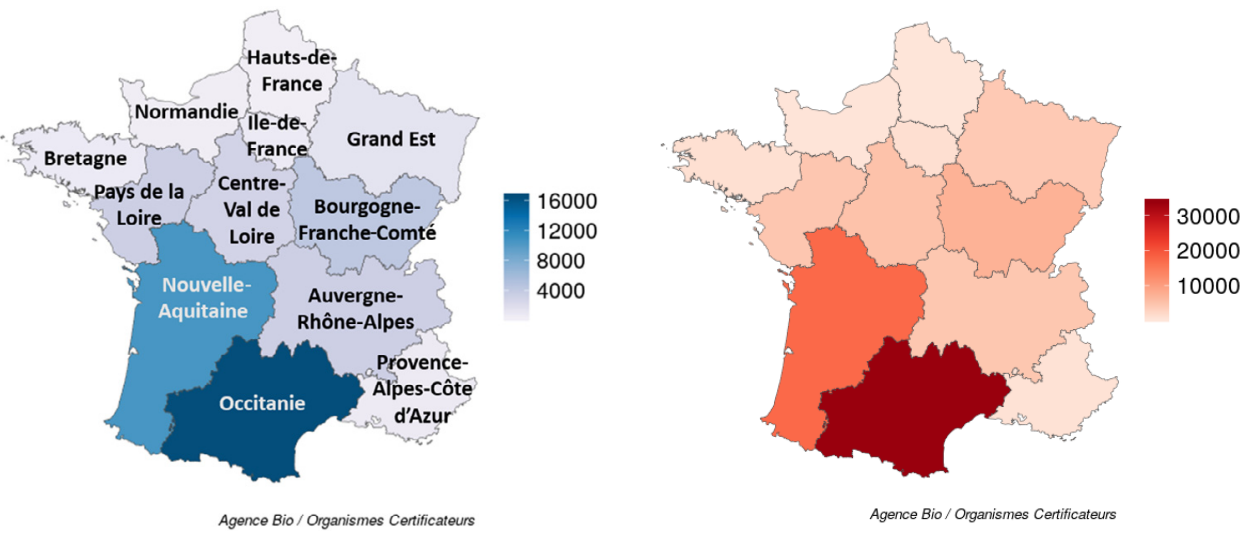

Fig. 2. Evolution from 2014 to 2018 of areas cultivated under organic conditions of oilseed and protein crops from several French regions (From Agence Bio, 2019).

Table 1. Groups of regions defined for the organic sunflower survey in 2017.

\begin{tabular}{llll}
\hline $\begin{array}{l}\text { Groups defined for } \\
\text { sunflower survey (2017) }\end{array}$ & Southern regions & Western-center regions & Northern and Eastern regions \\
\hline Regions & $\begin{array}{l}\text { Occitanie ex Aquitaine } \\
\text { Auvergne-Rhône-Alpes, PACA }\end{array}$ & Pays de la Loire, ex Poitou-Charentes & Other regions \\
$\begin{array}{l}\text { Number of farmers who } \\
\text { answer the questionnaire }\end{array}$ & $\begin{array}{l}70 \\
(\% \text { of total answers) }\end{array}$ & 30 & $\mathbf{8}$ \\
\hline
\end{tabular}

Table 2. Groups of regions defined for the organic soybean survey in 2016 .

\begin{tabular}{lll}
\hline Region groups defined for soybean survey (2016) & Southern regions & Northern and Eastern regions \\
\hline Regions & Occitanie Ancienne Aquitaine & Other regions \\
Number of farmers who answer the questionnaire & Auvergne-Rhône-Alpes, PACA & $\mathbf{1 2}$ \\
(\% of total answers) & 68 & $(5 \%)$ \\
\hline
\end{tabular}




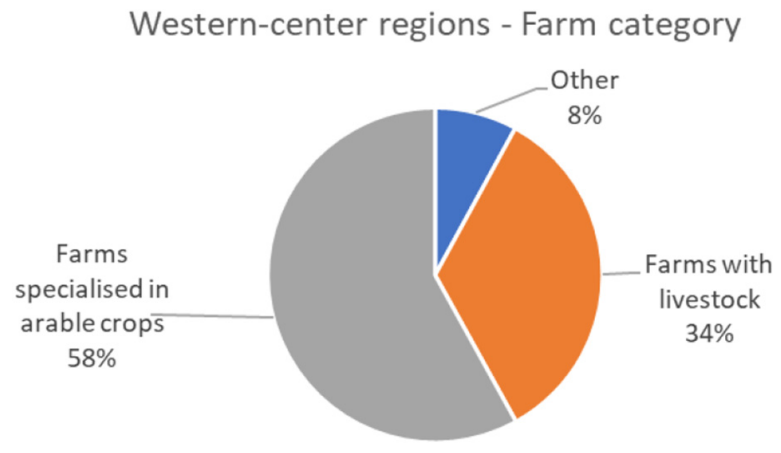

- Other - Farms with livestock $\quad$ - Farms specialised in arable crops

Fig. 3. Farm category of farms with organic sunflower-Westerncenter regions.

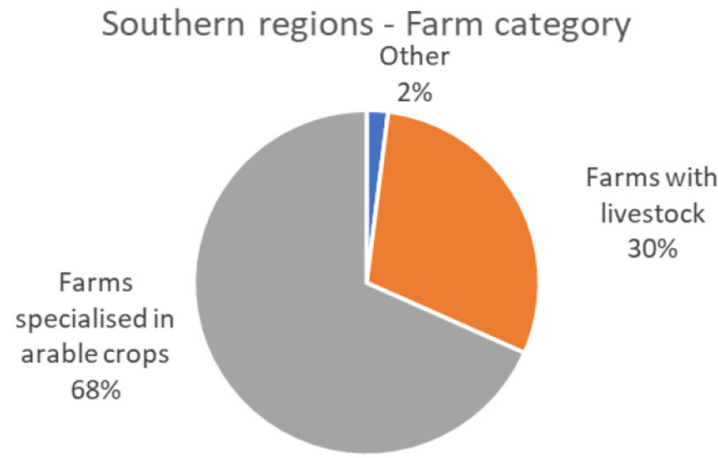

- Other - Farms with livestock = Farms specialised in arable crops

Fig. 4. Farm category of farms with organic sunflower-Southern regions.

Table 3. Number of different crops in the 5 years preceding sunflower on the southern and western center regions.

\begin{tabular}{|c|c|c|c|c|}
\hline$\frac{\text { Regions }}{\text { Production }}$ & \multicolumn{2}{|c|}{ Southern regions } & \multicolumn{2}{|c|}{ Western-center regions } \\
\hline $\begin{array}{l}\text { Number of different crops sown in the } \\
5 \text { years preceding sunflower }\end{array}$ & 4 & 2 & 4 & 3 \\
\hline
\end{tabular}

\section{Western-center regions - Plant losses before emergence or just after}

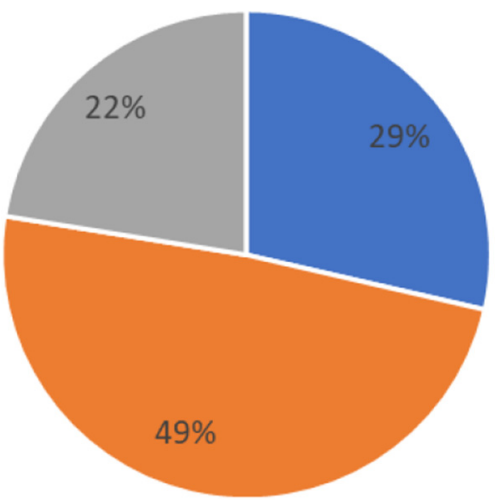

- No plant losses

- Lot of plant losses

- Some plant losses

Fig. 5. Plant losses before or just after emergence-Western-center regions.

converted to organic farming). Moreover, on the southern area, $16 \%$ of the total survey area was weeded manually $(9 \%$ on the western-center area). This practice is very effective to control emerging infestations.

In 2017, insufficient weed control was declared only for $8 \%$ of the surveyed fields. This very good result is partly due to the spring climatic conditions (with almost no rain and so not favourable to weeds re-emergence after hoeing) and partly to very good control through mechanical weeding. In the 2011

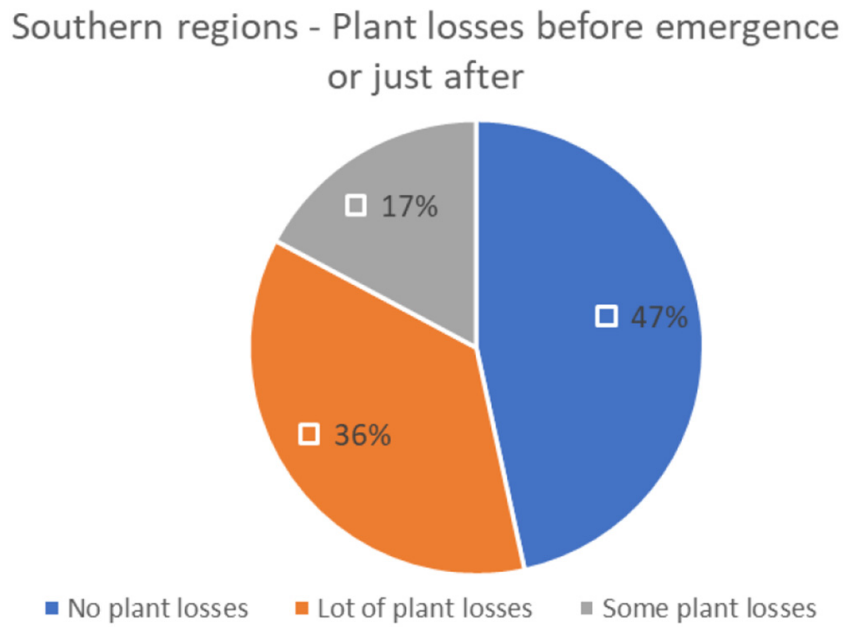

Fig. 6. Plant losses before or just after emergence-Southern regions.

survey, with a rainier spring, insufficient weed control was declared on $21 \%$ of the surveyed fields.

\subsection{However, lower yields for organic sunflower}

The average sunflower yield for 2017 was of $22 \mathrm{q} / \mathrm{ha}$, a little higher than the average yield obtained over the 5 previous years $(21 \mathrm{q} / \mathrm{ha})$. A slight difference was observed between the two surveyed production areas as shown in Table 4. 


\section{Western-center regions - Ploughing}

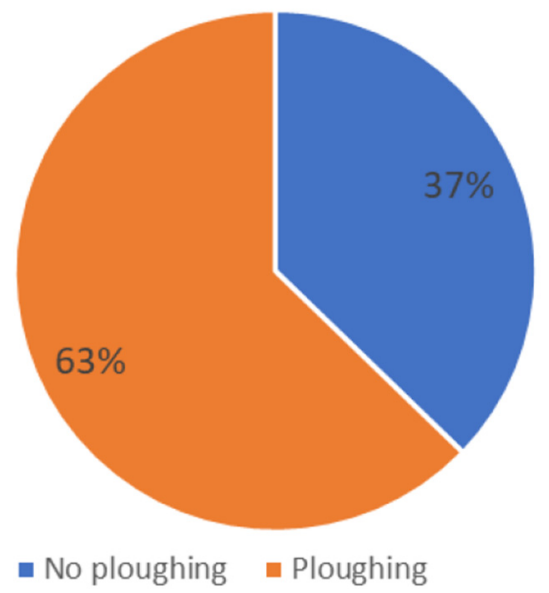

Fig. 7. Plant losses before or just after emergence-Western-center regions.

Compared to conventional sunflower, these results are disappointing since in 2017, the average yield obtained for conventional sunflower was $30 \mathrm{q} / \mathrm{ha}(28 \mathrm{q} / \mathrm{ha}$ for the southern area and 32.5 for the western center area). This difference was already observed in 2011 but was much lower.

The year 2017 was very favourable to sunflower, with very good conditions over April to sow sunflower and ensure a very good emergence rate, few damages due to birds and rainfalls relatively important during flowering. Nevertheless, as mentioned previously, organic sunflower was sown very late compared to conventional sunflower and could not benefit from these good conditions.

This difference of yields was also observed in other cases like in the MASCOT experiment (Mediterranean Arable Systems COmparison Trial) from 2002 to 2004, where the sunflower yield in organic system was lower from $20 \%$ to $40 \%$ compared to conventional system (Mazzoncini et al., 2006).

\section{Soybean: the star of crop rotations in the South of France}

\section{1 market still driven by human consumption}

In $2016,70 \%$ of the surveyed areas were produced for human consumption and only $30 \%$ for livestock feeding. In 2012, human consumption was already the main outlet for organic soybeans ( $70 \%$ of the surveyed area). This is different from conventional soybean, where soybean for human consumption represents only $38 \%$ of the surveyed area (results obtained from the survey conducted by Terres Inovia on agricultural practices for non organic soybean in 2016). This situation can be explained by different factors. Firstly, the need of the human consumption value chain is strong since 2010, both for organic and non organic production. However, for non organic soybean, the market was already driven by feed sector at this time and the outlet for human consumption was not very important compared to the demand of feed. For non organic

\section{Southern regions - Ploughing}

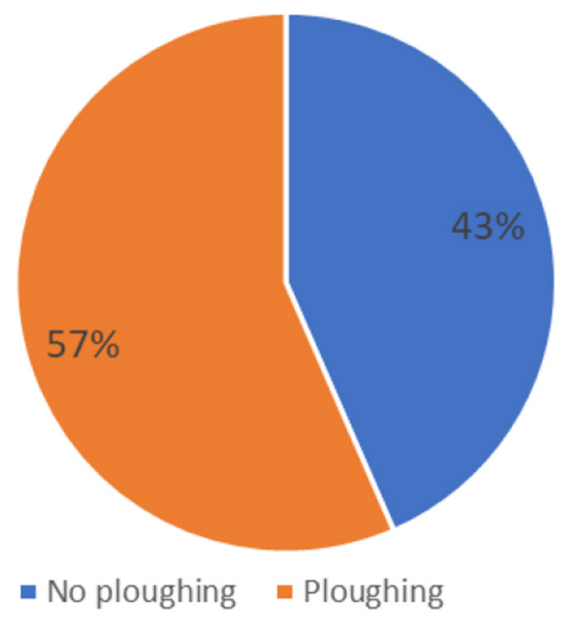

Fig. 8. Plant losses before or just after emergence-Southern regions.

production, production for human consumption has stayed a "niche" outlet. For organic soybean, production in France was just beginning in 2010 and the demand of the feed sector, for organic cattle, was still low; in this context, the outlet for human consumption was attractive for organic producers and the organic soybean value chain was build to answer the demand of the food sector. This development was also facilitated because organic soybean production concerned first and foremost the South of France, where climatic conditions were favourable to obtain a very good grain quality, which is required for human consumption outlet. Moreover, selling price of soybean for the human consumption outlet is significantly higher than for the livestock outlet, and so, producers target the human consumption market. Nevertheless, since 2016, this trend has evolved with more and more soybean dedicated to livestock feed market. Firstly, because the human consumption market stagnates and so the demand does not increase anymore, whereas the production of organic soybean is still currently rising. Secondly, because the demand for livestock feed (and particularly poultry) is presently blowing up (and prices also); moreover, some value chains have chosen to valorize a production "100\% made in France" from field to plate, and ask for French soybean only for the cattle. This trend is recent and so could not be seen in 2016 .

\subsection{More soybean in organic crop rotations than in conventional ones, particularly in irrigated situations}

In contrast with sunflower, the return rate of soybean in organic crop rotations is higher than in conventional crop rotations, as shown in Table 5 which compared the number of soybeans present in the crop succession from 2011 to 2016 over the five years before the 2016 survey.

Nevertheless, this trend hides great differences between irrigated and non-irrigated systems as shown in Table 6 . Indeed, for non-irrigated soybean, $45 \%$ of the surveyed area received no soybean over the 5 years before the survey whereas 
Table 4. Average yield ( $\mathrm{q} / \mathrm{ha})$ of southern and western center regions.

\begin{tabular}{|c|c|c|c|c|}
\hline $\begin{array}{l}\text { Regions } \\
\text { Production }\end{array}$ & \multicolumn{2}{|c|}{ Southern regions } & \multicolumn{2}{|c|}{ Western-center regions } \\
\hline Yield of organic sunflower $(\mathrm{q} / \mathrm{ha})$ & 21.5 & 28 & 24 & 32.5 \\
\hline
\end{tabular}

Table 5. Percentage of surveyed areas with 0 to 3 soybeans in the crop rotation from 2011 to 2016 in organic and conventional systems.

\begin{tabular}{lll}
\hline Number of soybean in crop rotation & \% of surveyed area for organic soybean & \% of surveyed area for conventional soybean \\
\hline Without soybean & 27 & 55 \\
With one soybean & 35 & 25 \\
With two soybeans & 23 & 19 \\
With three soybeans & 15 & 1 \\
\hline
\end{tabular}

Table 6. Percentage of surveyed areas with 0 to 3 soybeans in the crop succession from 2011 to 2016 in organic systems, in irrigated and nonirrigated fields.

\begin{tabular}{lll}
\hline Number of soybean in crop rotation & $\begin{array}{l}\text { \% of surveyed area for non } \\
\text { irrigated organic soybean }\end{array}$ & $\begin{array}{l}\text { \% of surveyed area for } \\
\text { irrigated organic soybean }\end{array}$ \\
\hline Without soybean & 45 & 16 \\
With one soybean & 46 & 27 \\
With two soybeans & 9 & 32 \\
With three soybeans & 0 & 25 \\
\hline
\end{tabular}

it concerned only $16 \%$ of the irrigated surveyed area; and conversely, for non irrigated soybean, surveyed area with 2 or 3 soybean present over the 5 represented only $9 \%$ whereas it concerned $57 \%$ of the surveyed of irrigated soybean.

For irrigated systems, it implies that crop successions can be poorly diversified. Such short rotations based on soybean were also observed in Northern Italy on organic farms (Dal Ferro et al., 2017). Several reasons explain this "domination" of soybean in irrigated crop successions. Firstly, soybean is not concerned by a large range of pests and diseases in the systems of South West of France (except on some territories, where sclerotinia is often observed): this enable producers to reduce the return rate without penalizing the yield (which is high) and so the profitability of the crop. Secondly, the price of organic soybean, notably for human consumption outlet, is very high: soybean is so a very profitable crop, compared to corn for example. In conventionel production systems, soybean is often less profitable, in irrigated or non irrigated systems. This explains why soybean is less present in crop successions. The profitability of organic soybean was also reported in other countries like in the USA (McBride and Greene, 2009; Hartman et al., 2016): in 2016, Hartman reported that organic soybean price for food was about 24 USD for feed, whereas conventional soybean price was only of 9 USD for feed. This great difference of price induced a great difference of profitability of soybean between organic and conventional systems, even if operating costs per acre were slightly higher for organic production (103 USD/acre vs 92 USD/acre; McBride and Greene, 2009).

\subsection{More soybean cultivated without irrigation for organic production}

While soybean is more profitable when it is irrigated, the survey of 2016 reveals that a great part of organic soybean ( $40 \%$ of the surveyed area) is produced on non-irrigated fields. It contrasts with conventional soybean production where nonirrigated soybean represented only $11 \%$ of the total surveyed area. This trend highlights that, in organic systems of the South West of France, soybean "dominates" the irrigated crop rotations (as explained in the previous paragraph) but is also an important crop for non-irrigated crop rotations, contrary to conventional systems. This difference is mainly explained by the difference of profitability of non irrigated soybean in the two kind of systems. Indeed, even if the yield is greatly penalized by the lack of water (loss from $30 \%$ to $60 \%$ ), organic soybean is still as profitable (even more profitable) than other crops cultivated in the same conditions, because selling price is very high compared to them. That is not the case in conventional systems, where non irrigated corn or wheat is often more profitable for example. In these situations, to limit the impacts of the lack of irrigation on yield, producers increase the sowing density (from 450000 seeds/ha to $465000 \mathrm{seeds} / \mathrm{ha}$ in average in the survey conducted in 2016). 
For organic soybean cultivated for human consumption outlet, irrigation was more common than for soybean cultivated for livestock feed (59\% vs 50\% of the surveyed area). Indeed, irrigation ensures to reach a good protein rate in soybeans, which is a qualifier criterion for human consumption market (rates higher than $40 \%$ or $41 \%$ are commonly required).

\subsection{A strengthened soybean weed control to satisfy human consumption market requirements}

The most difficult weeds to control were, without surprise, the same as for sunflower. However, only $17 \%$ of the surveyed fields were evaluated by producers as "badly weeded" considering their attents and also their equipment. This result is similar to those obtained in the 2012 survey (11\%) but far more important than for conventional soybean (only $2 \%$ ). Weed control is the most important challenge in organic soybean production in France, but also in other countries like in China (where Knudsen et al., 2010 observed that labour time dedicated to weed suppression was 4 times more important in organic production than in conventional production) or in the USA (McBride and Greene, 2009).

In average, soybean was weeded 3.8 times. As an example, the number of weeding was nearby twice as sunflower, and higher than what was observed by McBride and Greene (2009): 1.5 times in average. This difference is due to (i) less competition ability especially when planted in large rows (most common way in the southern regions), (ii) a better tolerance of soybean to mechanical weeding and (iii) more strict requirements for soybean on the impurity content, and particularly towards some weed grains which are toxic for humans (black nightshade (Solanum nigrum) and datura (Datura stramonium) for example) or penalize the visual aspect of the grain (black nightshade). These weeds cannot be eliminated only through mechanical weeding. Hand weeding is often the most effective way but is only used for high profitable crops like soybean or pop-corn. That explains why $56 \%$ of the soybean surveyed areas were hand weeded (instead of only $16 \%$ for sunflower).

Ploughing was done on $66 \%$ of the organic soybean surveyed areas whereas it concerns only $41 \%$ of the conventional surveyed areas. Indeed, in conventional systems, producers give up ploughing more and more but not in organic systems, in which ploughing is one of the best ways to control weeds. The same observation was made by McBride and Greene (2009) in the USA where ploughing was used by $36 \%$ of organic producers whereas $50 \%$ of conventional producers used a no-till planter.

\subsection{Lower yields for organic soybean compared to conventional soybean}

In 2016 , the organic average yield is $19.9 \mathrm{q} /$ ha but is very different between irrigated soybean $(25.2 \mathrm{q} / \mathrm{ha})$ and nonirrigated (12.6 q/ha). The low yields obtained in non-irrigated conditions were due to strong drought from spring to harvest.

Conventional soybean yields obtained the same year were equal of $32 \mathrm{q} / \mathrm{ha}$ in irrigated conditions and $19 \mathrm{q} / \mathrm{ha}$ in nonirrigated ones, in average. This great difference between organic and conventional systems cannot be so easily explained. Indeed, in the context of the South of France, the only significant difference between organic and conventional soybean practices is about weeding practices. Such a poor diference in practices between those two systems is quite rare regarding other french crop managment. And in the 2016 context, pests and diseases were not a problem. This difference of yield between organic and conventional production was observed in several countries where organic soybean is cultivated, like in China (Knudsen et al., 2010; Zhang et al., 2015) or in the USA (McBride and Greene, 2009; Hartman et al., 2016), where organic yields were lower from $10 \%$ to $20 \%$ compared to conventional yields.

\section{Conclusions}

Each of these surveys is a photography of the practices set up by producers for a given year. For sunflower, it shows that organic cultivation mainly differs from conventional cultivation on three points: crop rotation, sowing date and weed control. Of course, pest and disease management were also different, but they were little damages due to them reported by producers in the survey. Organic sunflower was fertilized over $57 \%$ of the cultivated area whereas $74 \%$ of the conventional cultivated area received mineral fertilizers. However, it is difficult to estimate through this survey if lack of fertilization impacts the yield severely or not. For soybean, the main differences concern irrigation (more systematic in conventional systems), weed control and crop rotation. Surprisingly, soybean was more frequent in crop rotation in organic systems than in conventional systems, particularly when it was irrigated. This demonstrate its high profitability but also the high "technicality" of the producers. Indeed, in short rotations, diseases and weed pressure are more important. To be able to maintain a good yield and the balance of the system, soybean producers manage very carefully irrigation (to limit diseases) and weed control (with much more operations than sunflower and hand weeding in complement). Beside its high profitability, it must be mentioned that soybean is also a legume crop and a very good previous crop for cereals and maize, and do not require nitrogen fertilizers to grow. This explain why this crop is so present in the organic systems in the South of France.

These surveys enable to better characterize these practices, to identify the dominant ones but also to explore their diversity, on the different production areas. Their repetition over the years also enable to follow the evolution of these practices. Nevertheless, their main weak point is the response rate, particularly for the production areas where sunflower and soybean are not the main crops of the rotation. To enhance this response rate in the next years, we should involved the local actors like storage agencies, to increase the number of targeted producers and to relay the information about our surveys alongside their adherents.

These surveys provide some critical elements to be able to perform an agronomic diagnosis for the different crops that are surveyed, but also to build economic references (based on the average data obtained on the cropping practices) and then, to orientate research programs with a view to increase the competitiveness of these different crops within the French cropping systems. 


\section{References}

Agence Bio. 2019. Données départementales et régionales de certification au 31 décembre de 2011 à 2019. Les données sont disponibles sur https://www.agencebio.org/vos-outils/les-chiffres-cles/.

Dal Ferro N, Zanin G, Borin M. 2017. Crop yield and energy use in organic and conventional farming: A case study in Northeast Italy. Eur J Agron 86: 37-47.

Hartman GL, Pawlowski ML, Herman TK, Eastburn D. 2016. Organically grown soybean production in the USA: Constraints and management of pathogens and insect pests. Agronomy 6(1): 16.

Knudsen MT, Yu-Hui Q, Yan L, Halberg N. 2010. Environmental assessment of organic soybean (Glycine max.) imported from
China to Denmark: A case study. J Clean Prod 18(14): 1431-1439.

Mazzoncini M, Barberi P, Belloni P, Cerrai D, Antichi D. 2006. Sunflower under conventional and organic farming systems: Results from a long-term experiment in Central Italy. Aspects Appl Biol 79. In: What will organic farming deliver? COR 2006, pp. 125-129.

McBride WD, Greene C. 2009. The profitability of organic soybean production. Renew Agric Food Syst 276-284.

Zhang LW, Feike T, Holst J, Hoffmann C, Doluschitz R. 2015. Comparison of energy consumption and economic performance of organic and conventional soybean production - A case study from Jilin Province, China. J Integr Agric 14(8): 1561-1572.

Cite this article as: Le Gall C, Lecomte V, Wagner D. 2022. Oilseed and protein crops grown in French organic farms: an overview of cultivation practices for sunflower and soybean. OCL 29: 4. 